\title{
Harga Diri pada Pendukung Pelaku Hate Speech di Media Sosial
}

\author{
Efi Lia Nurnanda ${ }^{1}$ \\ Universitas Muhammadiyah Malang \\ e-mail: ${ }^{1}$ efiliann14@gmail.com
}

\begin{abstract}
Hate speech is a form of communication between individuals that involves denigrating, harrassing, intimidating or inciting hatred (provocation) towards individuals in certain groups or individuals, based on race, religion, gender or sexual orientation. The increase in cases of hate speech online makes researchers interested in conducting research on how the emergence of hate speech behavior in based on one of the factors, self-esteem. This study aims to analyze and describe selfesteem in hate speaker supporters on social media. This research incorporates a descriptive quantitative research model. The subjects of this study amounted to 149 people, aged 18-25 years who were selected using the accidental sampling technique. The research instruments in the present study are hate speech scale and self esteem scale. The results of this study indicate that hate speaker supporters tend to have a high level of self-esteem (52,3\%) and moderate level of self-esteem $(47,7 \%)$.
\end{abstract}

KEYWORDS hate speech, self esteem, social media

CITATION Nurnanda, E. L. (2020). Harga diri pada pendukung pelaku hate speech di media sosial. Cognicia, 8, (2). 296-311.

Perkembangan teknologi informasi saat ini telah menjadi lebih canggih, cepat, dan lebih mudah dari sebelumnya. Di era yang semakin modern, individu bisa dengan mudah melakukan interaksi jarak jauh dengan menggunakan aplikasi-aplikasi obrolan seperti whatsapp, line, kakaotalk, twitter, facebook, instagram, e-mail, dan lain-lain yang bisa diakses dengan mudah menggunakan data internet. Berdasarkan survei yang telah dilakukan oleh Asosiasi Penyelenggara Jasa Internet Indonesia (APJII) di Indonesia, jumlah pengguna internet tahun 2017 telah mencapai 143,26 juta jiwa atau setara dengan $54,68 \%$ dari total jumlah penduduk Indonesia. Jumlah tersebut menunjukan kenaikan sebesar 10,56 juta jiwa dari hasil survei pada tahun 2016.

Berdasarkan survey yang dilakukan Hootsuite (2019), usia rata-rata pengguna media sosial paling banyak adalah 18-34 tahun, baik laki-laki maupun wanita. Menurut Harlock (2012), rentang usia tersebut masuk ke dalam masa dewasa awal (18-40 tahun), dimana pada masa ini terdapat perubahan-perubahan yang nampak antara lain perubahan dalam hal penampilan, fungsi-fungsi tubuh, sikap, minat, serta tingkah laku sosial.

Menurut Raharjo (dalam Harefa, 2017) meskipun penggunaan internet pada satu sisi membawa perubahan positif pada bidang kehidupan, sosial, ekonomi dan sebagainya, namun pada sisi lain juga menimbulkan perubahan paradigma dalam studi mengenai kejahatan. Dampak negatif yang sering terjadi dengan kemudahan 
berkomunikasi dan bertukar informasi melalui jejaring sosial adalah penyebaran suatu berita yang memiliki muatan negatif seperti penghinaan atau pencemaran nama baik. Pada keadaan inilah, perbuatan tersebut masuk ke dalam perbuatan tindak pidana, karena status yang dituliskan berisi ujaran kebencian (hate speech). Hate speech (ujaran kebencian) merupakan bentuk komunikasi antar individu yang bersifat menjelekkan, melecehkan, mengintimidasi atau menghasut kebencian (provokasi) terhadap individu dalam kelompok tertentu atau perseorangan, berdasarkan ras, agama, jenis kelamin ataupun orientasi seksual.

Hate speech atau ujaran kebencian ditujukan tidak hanya pada publik figur, namun juga pada masyarakat awam. Bentuk hate speech (ujaran kebencian) dalam Surat Edaran (SE) Kapolri No SE/06/X/2015 yaitu penghinaan, pencemaran nama baik, penistaan, perbuatan tidak menyenangkan, memprovokasi, menghasut, dan menyebarkan berita bohong. Semua tindakan ini memiliki tujuan atau berdampak pada tindak diskrimikasi, kekerasan, penghilangan nyawa atau konflik sosial sehingga dapat mengakibatkan stres dan depresi pada para korbannya.

Kasus hate speech semakin tinggi tiap tahunnya dan pihak berwenang sendiri hanya mampu menyelesaikan tiga-perempat dari keseluruhan kasus yang terjadi tiap tahunnya. Pada tahun 2017, Polri telah menangani 3.325 kasus kejahatan hate speech atau ujaran kebencian Angka tersebut naik 44,99\% dari tahun sebelumnya, yang berjumlah 1.829 kasus. Kasus yang mampu diselesaikan tahun 2017 tersebut ada sekitar 2.108 kasus. Adapun tindak pidana hate speech yang paling banyak terjadi adalah kasus penghinaan, yaitu 1.657 kasus, atau naik 73,14\% dibanding pada 2016. Kemudian, hate speech dengan kasus perbuatan tidak menyenangkan sebanyak 1.224 kasus. Sedangkan hate speech dengan kasus pencemaran nama baik sebanyak 444 kasus.

Ada beberapa kasus hate speech yang berujung penjara, misalnya pada kasus Arseto Suryoadji yang mendapatkan hukuman 2 tahun penjara setelah terbukti menyebarkan isu SARA lewat facebook dengan cara memfitnah Jokowi. Kasus bermula ketika Arseto mem-posting status di akun facebook miliknya pada tanggal 24 Maret 2018, ia menulis status yang bermuatan SARA. Setelah itu, ia kembali menulis status bermuatan SARA sehingga memicu kebencian dan permusuhan (Detik.com, 2018). Kemudian ada kasus lain tentang musisi Ahmad Dhani yang terjerat pasal 28 ayat 2 juga pasal 45 ayat 2 UU ITE dan diancam hukuman pidana 6 tahun atau denda 1 miliar setelah menulis status yang berbunyi "siapa saja yang mendukung penista agama adalah bajingan yang perlu diludahi mukanya" di akun twitternya pada 6 Maret 2017 (Liputan6.com, 2018). Kemudian, kasus terbaru yang terjadi adalah kasus AH alias pendukung Anies Baswedan dilaporkan setelah dianggap membawa spanduk berisikan ujaran kebencian yang ditujukan pada Presiden Jokowi pada saat berunjuk rasa di depan balai kota (Tribunnews.com, 2020).

Di dalam kasus hate speech, tak hanya ada satu pelaku dan satu korban, namun bahkan beberapa pelaku-pelaku tersebut juga memiliki dukungan dibelakang mereka yang merasa bahwa individu tersebut memiliki pendapat yang sama dengan pelaku yang melakukan hate speech tersebut. Di dalam KBBI (Kamus Besar Bahasa Indonesia), pendukung adalah seseorang yang menyokong, menunjang dan membantu individu atau suatu objek. Dapat disimpulkan bahwa pendukung hate speech berarti seseorang 


\section{Cognicia}

http://ejournal.umm.ac.id/index.php/cognicia
ISSN 2658-8428

2020, VOL. 8, NO. 2, 296-311

yang memberikan dukungan, menyokong, menunjang dan membantu individu yang melakukan tindakan hate speech atau mendukung objek yang mengandung kebencian pada suatu individu atau kelompok tertentu.

Dampak dari perilaku hate speech diantaranya : (a) dampak bagi pendukung atau bahkan pelaku kejahatan hate speech, individu tersebut bisa mendapatkan tuntutan dari korban, mendapatkan sanksi hingga dipenjara. Menurut pendapat Elizabeth Santosa, seorang psikolog dari Swiss German University (SGU), individu yang melakukan hate speech bisa mengalami masalah psikologi seperti menjadi individu yang impulsif (individu mendapatkan dorongan untuk melakukan sebuah tindakan tanpa memikirkan konsekuensinya), managemen emosinya menjadi berantakan dan kurang percaya diri (Heath.detik.com, 2015). Sedangkan (b) dampak bagi korban kejahatan hate speech ini, seperti menurut survey yang telah dilakukan oleh Ditch the Label, sebuah kegiatan amal anti bullying nasional di Inggris, korban mengatakan bahwa efek terburuk dari tindakan hate speech adalah jatuhnya harga diri mereka dalam kehidupan sosial, serta merusak masa depan dengan cara menghancurkan optimisme dalam diri mereka.

Penelitian yang dilakukan ilmuwan dari National Institutes of Health (NIH) mengungkapkan kekerasan melalui dunia maya efeknya lebih besar terhadap korban. Kekerasan dunia maya ternyata lebih menyakitkan jika dibandingkan dengan kekerasan yang dilakukan secara fisik. Menurut Mardiyati (2017), bentuk-bentuk dari hate speech ini yang sudah mengarah pada bentuk kejahatan cyber (cyber crime) yang berpengaruh pada masalah keamanan nasional dan stabilitas negara.

Fenomena hate speech di media sosial ini tidak hanya dapat ditinjau dari perspektif hukum namun juga dari tinjauan psikologi. Bentuk-bentuk dari ujaran kebencian dalam Surat Edaran (SE) Kapolri No SE/06/X/2015 seperti penghinaan, pencemaran nama baik, penistaan, perbuatan tidak menyenangkan, memprovokasi, menghasut, dan menyebarkan berita bohong termasuk dalam bentuk agresi verbal. Menurut Buss dan Denni (dalam Syarif, 2017), agresi verbal (verbal agression) yaitu agresivitas yang dilakukan dengan kata-kata, dapat berupa umpatan, sindiran, fitnah, dan sarkasme. Sedangkan menurut teori Crick dan Grotpeter (dalam Hastuti, 2018), memberikan contoh agresi verbal bisa berupa membentak, mengolok-olok, dan melecehkan. Sementara itu, menurut Anne Weber (dalam Mardiyati, 2017), hate speech adalah mencakup semua bentuk ekspresi yang menyebarkan, menghasut, membenarkan kebencian rasial, xenophobia (ketakutan atau ketidaksukaan terhadap orang-orang dari negara lain) dan deskriminasi serta permusuhan terhadap minoritas, migran, dan orang-orang yang berasal dari imigran.

Agresi verbal sendiri menurut Buss (dalam Dayakisni dan Hudaniah, 2012) dikelompokkan dalam empat jenis, yaitu agresi verbal aktif langsung, agresi verbal pasif langsung, agresi verbal aktif tidak langsung dan agresi verbal pasif tidak langsung. Dari pengertian hate speech yang dikemukakan oleh Anne Weber, hate speech dapat dikategorikan sebagai agresi verbal aktif tidak langsung, yaitu tindakan agresi verbal yang dilakukan oleh individu atau kelompok dengan cara tidak berhadapan secara langsung dengan individu atau kelompok lain yang menjadi targetnya, seperti dengan cara menyebar fitnah dan mengadu domba. Menurut Hinduja dan Patchin (dalam 


\section{HATE SPEECH, SELF ESTEEM, SOCIAL MEDIA}

Hastuti, 2018), sejalan dengan berkembangnya zaman, agresi menjadi lebih luas dan seringkali menggunakan alat elektronik sebagai medianya.

Pada penelitian tentang hate speech yang telah dilakukan oleh Auwal (2018) tentang Social Media and Hate Speech, mendapatkan hasil bahwa kebebasan menggunakan sosial media di Nigeria menyebabkan penyalahgunaan platform tersebut untuk mengekspresikan pandangan mereka tentang isu-isu nasional. Banyak komentar kebencian mendominasi ruang media sosial terutama facebook, yakni komentarkomentar pengguna mengenai kejadian Biafra dan Ultimatum Pemuda Arewa yang merupakan isu masalah sensitif di Nigeria. Komentar-komentar tersebut berisikan serangan atau dukungan pada kelompok etnis atau agama tertentu, dan juga menyerang orang-orang tertentu. Hal tersebut memicu kemarahan dan reaksi kekeran serta membuat beberapa orang menyerang bangsa mereka sendiri. Penelitian lain dilakukan oleh Pen (2015) berjudul "Hate Speech: A Study of Print, Movies, Songs and Social Media in Myanmar", dengan kesimpulan bahwa sebagian besar film yang telah ditayangkan di media setiap hari, termasuk lagu-lagu, banyak yang berisi hasutan untuk melakukan kekeran, tantangan dan diskriminasi terhadap orang lain. Hal tersebut menyebabkan perasaan benci terhadap etnis lain.

Barbara Krahe (dalam Sentana \& Kumala, 2017) mengemukakan beberapa faktor penyebab agresivitas, yaitu (a) faktor kepribadian yakni iritabilitas, kerentanan emosional, pikiran kacau versus perenungan, kontrol diri (self control), harga diri (self esteem) dan gaya atribusi bermusuhan, dan (b) faktor situasional, diantaranya yakni adanya penyerangan, efek senjata, dan karakteristik target. Dari penjelasan tersebut, salah satu faktor yang dapat menyebabkan perilaku hate speech yaitu harga diri (self esteem) yang dikemukakan oleh Krahe (dalam Sentana \& Kumala, 2017).

Menurut Santrock (2013), harga diri adalah keseluruhan cara yang digunakan individu untuk mengevaluasi diri, membandingkan antara konsep diri yang ideal (ideal self) dengan konsep diri yang sebenarnya (real self). Baron \& Byrne (2000) berpendapat harga diri merupakan evaluasi diri yang dibuat setiap individu, sikap orang terhadap dirinya sendiri dalam rentang positif sampai negatif atau rendah sampai tinggi. Semakin besar perbedaan antara konsep diri ideal dengan konsep diri yang sebenarnya, semakin rendah pula harga dirinya.

Adapun faktor-faktor yang mempengaruhi harga diri (self esteem) seorang individu menurut Coopersmith (Bashori \& Hidayat, 2016) yaitu, (a) penerimaan atau penghinaan terhadap diri sendiri, individu mampu menghargai dirinya, mengenali keterbatasan dirinya dan mempunyai harapan untuk maju, (b) kepemimpinan atau popularitas, individu menunjukkan perilaku yang sesuai dengan ekspektasi lingkungannya, (c) keluarga atau orang tua, perasaan dihargai oleh keluarga merupakan nilai penting dalam perkembangan harga diri, dan (d) keterbukaan dan kecemasan, individu cenderung terbuka ketika dirinya diterima dan dihargai dan individu akan mengalami kekecewaan apabila ditolak oleh lingkungannya. Kemudian, menurut Coopersmith (Bashori \& Hidayat, 2016), mengemukakan 3 aspek harga diri, yakni (a) perasaan berharga, (b) perasaan mampu, dan (c) perasaan diterima.

Pada penelitian sebelumnya tentang harga diri yang telah dilakukan oleh Morsunbul (2015) yang berjudul "The effect of identity development, self esteem, low-self 


\section{Cognicia}

control and gender on aggression in adolescence and emerging adulthood" mendapatkan hasil bahwa ada hubungan negatif antara harga diri dan agresi. Analisis menunjukkan bahwa harga diri memprediksi agresi secara negatif, yang artinya tingkat harga diri yang tinggi menurunkan tingkat agresi. Individu dengan harga diri rendah memiliki hubungan yang lemah dalam masyarakat dan hal tersebut menimbulkan lebih banyak kenakalan dan agresi.

Kemudian pada penelitian harga diri oleh Olutunde (2017) yang berjudul "Influence of perceived stress, anxiety, and self-esteem on aggressive behavior among teenagers" mendapatkan hasil bahwa ada hubungan positif yang signifikan antara agresi dan harga diri $(r=-0,166$ dan $\operatorname{sig}(0,01)<0,05)$ yang artinya semakin rendah tingkat harga diri, maka semakin tinggi tingkat agresinya. Lalu pada penelitian yang dilakukan oleh Singh dkk (2017) dengan judul "Aggression and self esteem among teenagers" mendapatkan hasil bahwa remaja berjenis kelamin laki-laki lebih agresif dari remaja berjenis kelamin perempuan. Remaja laki-laki juga memiliki level harga diri yang lebih tinggi daripada remaja perempuan.

Pada penelitian lain yang telah dilakukan oleh Ang dkk (2018) yang berjudul "Self-esteem and tendency of bullying among primary school children" mendapatkan hasil yang menunjukkan bahwa harga diri yang lebih tinggi mengarah pada perilaku intimidasi yang lebih tinggi. Analisis selanjutnya dalam sampel yang ditentukan oleh gender dan etnis, mendapatkan hasil bahwa ada perbedaan dalam perilaku intimidasi. Pelaku intimidasi berjenis kelamin laki-laki lebih banyak ditemukan daripada perempuan. Laki-laki cenderung menggunakan intimidasi secara fisik dan verbal, sedangkan perempuan lebih cenderung menggunakan intimidasi relasional. Selanjutnya, kelompok etnis mayoritas lebih cenderung terlibat dalam perilaku intimidasi dibandingkan dengan kelompok minoritas.

Encarta Dictionaries (2009) mendefinisikan hate speech (ujaran kebencian) sebagai ucapan atau tulisan yang dibuat seseorang yang bertujuan untuk menyebarkan dan menyulut kebencian sebuah kelompok terhadap individu atau kelompok lain yang berbeda, baik dari ras, agama, keyakinan, etnisitas, gender (jenis kelamin), kecacatan bahkan orientasi seksual. Hal diatas tidak sesuai dengan salah satu aspek harga diri oleh Coopersmitch (Bashori \& Hidayat, 2016) yakni perasaan mampu, dimana individu yang merasa mampu mencapai suatu hasil yang diharapkannya akan memiliki nilai-nilai dan sikap yang demokratis serta realistis yang artinya individu tersebut mampu untuk mengatur dan mengendalikan tingkah lakunya, mengikuti kode moral, etika, dan prinsip-prinsip keagamaan yang ditandai oleh ketaatan untuk menjauhi tingkah laku yang dilarang, dan melakukan tingkah laku yang diperbolehkan oleh moral, etika, dan agama. Individu sadar akan kekurangannya dan memiliki kemauan untuk melakukan perubahan. Namun tindakan yang menyebarkan dan menyulut kebencian antar individu atau kelompok termasuk individu dengan harga diri rendah karena individu tidak mampu mengatur dan mengendalikan setiap tindakannya.

Hal tersebut juga berlawanan dengan aspek yang dikemukakan oleh Coopersmitch (Bashori \& Hidayat, 2016) yakni perasaan berharga, dimana individu seharusnya merasa dirinya berharga dan mampu menghargai orang lain, individu merasa dirinya mampu mengontrol tindakannya dan mampu mengekspresikan diri 


\section{HATE SPEECH, SELF ESTEEM, SOCIAL MEDIA}

serta menerima kritikan dengan baik. Individu tersebut tidak mampu menghargai pendapat orang lain, tidak mengetahui kekurangannya dengan baik, enggan untuk melakukan perubahan dan menerima kritikan dengan buruk. Kemudian, menurut Kayambazinthu \& Moyo (2002), hate speech juga dipahami sebagai "teror verbal" atau perang yang dilakukan orang melalui kata-kata. Neilsen (dalam Auwal, 2018) juga menyebutkan bahwa hate speech dapat dimotivasi oleh semua jenis perbedaan yang dirasakan individu, yang artinya individu tersebut merasa tidak mendapatkan penerimaan, penghargaan dan perhatian atau apresiasi dari orang lain sehingga ia merasakan adanya perbedaan antara dirinya dengan orang lain. Hal tersebut juga menunjukkan bahwa individu yang melakukan tindakan hate speech memiliki harga diri yang rendah karena tak memiliki perasaan diterima atau individu tersebut merasakan adanya perbedaan, sehingga perasaan tersebut justru dikeluarkan dalam bentuk kebencian dan provokasi.

Hal ini tidak sesuai dengan aspek Coopersmitch (Bashori \& Hidayat, 2016) yakni perasaan diterima, dimana individu seharusnya memiliki perasaan dihargai dan diterima sebagai dirinya sendiri dalam suatu kelompok, namun individu dengan harga diri rendah cenderung melakukan tindakan tidak sesuai dengan kode moral, etika, dan prinsip-prinsip yang telah ditetapkan seperti halnya menghina dan merendahkan individu atau kelompok lain karena perbedaan yang individu tersebut rasakan. Individu yang terbiasa melakukan hate speech cenderung melakukan tindakan tidak sesuai dengan kode moral, etika, dan prinsip-prinsip yang telah ditetapkan seperti halnya menghina dan merendahkan individu atau kelompok lain dengan mengatakan bahwa mereka lebih rendah dalam beberapa hal atau menunjukkan bahwa mereka dihina atau tidak diterima. Hal itu kemudian akan memicu penyerangan fisik hingga menyebabkan reaksi kekerasan pada beberapa pihak yang merasa dirugikan. Dari penyataan-pernyataan diatas dapat disimpulkan bahwa individu dengan harga diri rendah (yang tidak mampu memenuhi aspek-aspek harga diri) cenderung akan melakukan tindakan hate speech (ujaran kebencian) di media sosial.

Adapun penelitian ini penting dilakukan untuk mencegah naiknya angka kasus perilaku hate speech di media sosial, serta diharapkan bisa meningkatkan harga diri (self esteem) pada individu untuk mencegah terjadinya perilaku hate speech dalam bersosialisasi di media sosial. Kemudian, penelitian ini juga penting untuk menjabarkan secara jelas sekaligus memperluas pengetahuan tentang perilaku hate speech yang saat ini semakin banyak terjadi seiring meningkatnya pengguna media sosial serta menjelaskan dampak negatif dari perilaku tersebut dari sisi psikologis.

Berdasarkan pemaparan diatas, tujuan dari penelitian ini adalah menganalisis dan mendeskripsikan harga diri pada pendukung pelaku hate speech (ujaran kebencian) di media sosial. Manfaat penelitian ini secara teoritis diharapkan dapat menambah dan mengembangkan ilmu pengetahuan saat ini maupun dimasa yang akan datang, serta bisa menjadi bahan rujukan, khususnya dalam dibidang psikologi sosial. Sedangkan manfaat praktisnya, yakni sebagai wawasan mengenai fenomena hate speech serta perilaku yang ditimbulkannya di media sosial dan bisa mengurangi dampak negatif dari penggunaan media sosial. Pengguna juga diharapkan bisa lebih bertanggung jawab 


\section{Cognicia}

http://ejournal.umm.ac.id/index.php/cognicia
ISSN $2658-8428$

2020, VOL. 8, NO. 2, 296-311

dalam bermedia sosial. Oleh sebab itu, penulis ingin melakukan penelitian dengan judul "Harga Diri pada Pendukung Pelaku Hate Speech di Media Sosial".

\section{METODE PENELITIAN}

Penelitian ini menggunakan metode penelitian deskriptif dengan pendekatan kuantitatif, yaitu metode yang digunakan untuk menganalisis atau membuat gambaran mengenai situasi atau kejadian yang ada (hasil penelitian) yang didapatkan dari populasi atau sampel yang telah ditentukan, pengumpulan data dilakukan dengan menggunakan instrumen penelitian dengan analisis yang bersifat statistik. Populasi yang digunakan yaitu subjek berjenis kelamin laki-laki maupun perempuan dan merupakan pengguna aktif media sosial yang berusia antara 18-25 tahun berjumlah 149 orang. Penelitian ini menggunakan metode accidental sampling yaitu pengambilan sampel yang dilakukan secara kebetulan atau siapa saja yang bertemu dengan peneliti dapat digunakan sebagai sampel (Sugiono, 2015). Pada penelitian ini terdapat satu variabel yaitu harga diri. Metode pengumpulan data dalam penelitian ini adalah dengan menggunakan dua skala yaitu skala pendukung yakni perilaku hate speech dan skala harga diri (self esteem). Skala ini menggunakan 4 alternatif pilihan jawaban "sangat setuju (SS)", setuju (S)", "tidak setuju (TS)" dan "sangat tidak setuju (STS)". Sedangkan skala harga diri (self esteem) menggunakan 2 alternatif pilihan "ya" dan "tidak".

Berdasarkan hasil dari uji validitas dan reliabilitas skala tryout yang dilakukan terhadap 64 orang subjek pada berusia 18-25 tahun yang aktif menggunakan media sosial, menunjukkan hasil uji validitas skala hate speech dimana dari 15 butir item, yang gugur ada sebanyak 3 item, sehingga total item valid sebanyak 12 item dengan rentang validitas 0,215 sampai dengan 0,690. Namun peneliti hanya menggunakan 4 item yaitu nomor 9-12 karena lebih mewakili konsep perilaku hate speech dibandingkan item lainnya. Kemudian pada skala harga diri, menunjukkan hasil uji validitas dimana dari 58 item, gugur sebanyak 22 item, sehingga total item ada sebanyak 36 item valid dengan rentang berkisar antara 0,219 sampai dengan 0,706. Kedua instrumen layak digunakan peneliti melihat dari angka reliabel masing-masing instrumen > 0,60 (cronbach's alpha), dengan reliabilitas skala hate speech adalah 0,808 dan reliabilitas skala harga diri adalah 0,907 .

Penelitian ini menggunakan tiga prosedur utama, yaitu persiapan penelitian, pelaksanaan penelitian dan analisis data. Pada tahap pertama, sebelum peneliti melakukan pengambilan data, peneliti melakukan try out pada skala penelitian. Dalam pengambilan subjek atau responden dalam try out didasarkan pada karakteristik yang tidak berbeda jauh dengan subjek penelitian, yaitu individu dengan rentang usia 18-25 tahun sebanyak 64 responden dan taraf kesalahan 5\%. Try out dilakukan menggunakan google form yang dilaksanakan pada tanggal 02 September 2019 - 16 September 2019.

Tahap selanjutnya adalah tahap pelaksanaan penelitian. Pada tahap ini, peneliti melakukan penelitian pada tanggal 21 September 2019 - 17 Oktober 2019. Sama seperti tahap pertama (try out), pada tahap ini peneliti juga menggunakan subjek penelitian yaitu individu dengan rentang usia 18-25 tahun, sebanyak 149 responden dan taraf kesalahan 5\%. Penelitian dilakukan menggunakan google form dengan pertanyaan maupun penyataan yang valid atau yang sudah diseleksi melalui try out sebelumnya. 


\section{HATE SPEECH, SELF ESTEEM, SOCIAL MEDIA}

Selanjutnya, pada tahap terakhir adalah tahap analisa data penelitian. Setelah data telah diperoleh dari penyebaran skala, peneliti kemudian melakukan skoring terhadap skalaskala yang telah disebar. Setelah itu, peneliti memasukkan nilai skor dari setiap item ke dalam Microsoft Excel 2010. Kemudian, data yang diperoleh dari excel diproses menggunakan IBM SPSS (Statistical Program for Social Science) 21 for Windows untuk dianalisa dengan menggunakan uji descriptive.

\section{HASIL PENELITIAN}

Subjek dari penelitian ini terdiri dari pengguna aktif media sosial berjumlah 149 orang dan berusia 18-25 tahun :

\section{Tabel 1. Deskripsi Subjek Penelitian}

\begin{tabular}{lcrl}
\hline \multirow{3}{*}{ Jenis Kelamin } & Kategori & \multicolumn{2}{c}{ Jumlah } \\
\cline { 2 - 4 } & Laki-laki & 36 & $(24,2 \%)$ \\
& Perempuan & 113 & $(75,8 \%)$ \\
\hline \multirow{3}{*}{ Usia } & 18 tahun & 25 & $(16,8 \%)$ \\
& 19 tahun & 36 & $(24,2 \%)$ \\
& 20 tahun & 17 & $(11,4 \%)$ \\
& 21 tahun & 13 & $(8,7 \%)$ \\
& 22 tahun & 31 & $(20,8 \%)$ \\
& 23 tahun & 20 & $(13,4 \%)$ \\
& 24 tahun & 6 & $(4 \%)$ \\
& 25 tahun & 1 & $(0,7 \%)$ \\
\hline
\end{tabular}

Berdasarkan gambaran hasil pada Tabel 1, dapat dilihat bahwa dari 149 subjek penelitian, didominasi oleh jenis kelamin perempuan sejumlah 113 orang $(75,8 \%)$ serta didominasi

\section{Tabel 2. Tingkat Harga Diri Pada Pendukung Pelaku Hate Speech}

\begin{tabular}{|c|c|c|c|}
\hline \multirow{2}{*}{ Harga Diri } & \multicolumn{3}{|c|}{ Kategori Hate Speech } \\
\hline & Jarang & Kadang & Sering \\
\hline Sedang & $8(11,3 \%)$ & $28(39,4 \%)$ & $35(49,3 \%)$ \\
\hline Tinggi & $13(16,7 \%)$ & $29(37,2 \%)$ & $36(46,1 \%)$ \\
\hline
\end{tabular}

Berdasarkan hasil pada Tabel 2, diketahui bahwa pada kategori subjek dengan tingkatan hate speech 'jarang' yang memiliki tingkat harga diri sedang sebanyak 8 orang $(11,3 \%)$, sementara yang memiliki harga diri tinggi ada 13 orang $(16,7 \%)$. Untuk kategori intensitas hate speech 'kadang-kadang' yang memiliki tingkat harga diri sedang ada sebanyak 28 orang $(39,4 \%)$, sedangkan tingkat harga diri tinggi sebanyak 29 orang $(37,2 \%)$. Kemudian, intensitas hate speech 'sering' dengan tingkat harga diri sedang berjumlah 35 orang $(49,3 \%)$ dan untuk tingkat harga diri tinggi pun sebanyak 36 orang $(46,1 \%)$. Kemudian, peneliti mengkategorikan tingkat aspek-aspek harga diri pada pendukung pelaku hate speech.

Tabel 3. Kategori Aspek-aspek Harga Diri

Aspek

Cognicia
Total Mean

Mean 


\begin{tabular}{ccc}
\hline A1 & $251,8(84,5 \%)$ & $1,69(84,5 \%)$ \\
\hline A2 & $241,3(81,0 \%)$ & $1,62(81,0 \%)$ \\
\hline A3 & $249,5(83,7 \%)$ & $1,67(83,5 \%)$ \\
\hline
\end{tabular}

Berdasarkan Tabel 3 diatas, A1 diatas mewakili aspek 1 yaitu "perasaan berharga", A2 mewakili aspek 2 yaitu "perasaan mampu" dan A3 mewakili aspek 3 yaitu "perasaan diterima". Selanjutnya, dari tabel diatas dapat disimpulkan bahwa aspek tertinggi dalam harga diri subjek yang melakukan hate speech cenderung menunjukkan A1 atau aspek 1 yang menunjukkan angka paling besar yaitu 84,5\%. Selanjutnya, peneliti kemudian mengkategorikan intensitas masing-masing aspek dalam perilaku hate speech.

Tabel 4. Kategori Aspek-aspek Perilaku Hate Speech

\begin{tabular}{ccc}
\hline Aspek & Total Mean & Mean \\
\hline A1 & $370(62,1 \%)$ & $2,5(62,5 \%)$ \\
\hline A2 & $380(63,7 \%)$ & $2,6(65,0 \%)$ \\
\hline
\end{tabular}

Berdasarkan Tabel 4 diatas, A1 mewakili aspek 1 yaitu "berdebat, menunjukkan ketidaksukaan atau ketidaksetujuan", dan A2 mewakili aspek 2 yaitu "bersikap sarkastis". Selanjutnya, pada tabel diatas hasil mean menunjukkan bahwa subjek cenderung melakukan perilaku dalam A2 atau aspek 2 yaitu "bersikap sarkastis" dalam melakukan tindakan hate speech di media sosial. Hal tersebut dapat ditunjukkan tabel diatas bahwa A2 merupakan nilai aspek tertinggi (65\%) dalam perilaku hate speech yang dilakukan. Peneliti kemudian mengukur kategori tingkat perilaku hate speech subjek berdasarkan jenis kelamin.

Tabel 5. Kategori Hate Speech Berdasarkan Jenis Kelamin

\begin{tabular}{lrc}
\hline \multirow{2}{*}{ Hate Speech } & \multicolumn{3}{c}{ Jenis Kelamin } \\
\cline { 2 - 3 } & \multicolumn{1}{c}{$\mathrm{L}$} & $\mathrm{P}$ \\
\hline Jarang & $6(33,3 \%)$ & $12(66,7 \%)$ \\
Kadang & $27(22,0 \%)$ & $96(78,0 \%)$ \\
Sering & $3(37,5 \%)$ & $5(62,5 \%)$ \\
\hline
\end{tabular}

Berdasarkan hasil dari Tabel 5. diatas, didapatkan hasil bahwa subjek dengan jenis kelamin laki-laki yang memiliki intensitas hate speech dengan kategori 'jarang' adalah sebanyak 6 orang (33,3\%), sedangkan untuk subjek berjenis kelamin perempuan adalah sebanyak 12 orang (66,7\%). Untuk kategori perilaku hate speech 'kadang-kadang', subjek berjenis kelamin laki-laki ada sebanyak 27 orang $(22 \%)$, sementara untuk subjek perempuan ada sebanyak 96 orang (78\%). Kemudian, untuk tingkat perilaku hate speech 'sering', subjek berjenis kelamin laki-laki ada sebanyak 3 orang $(37,5 \%)$, sementara untuk subjek perempuan ada sebanyak 5 orang $(62,5 \%)$. Dari penjabaran diatas, dapat disimpulkan bahwa baik subjek berjenis kelamin laki-laki maupun perempuan cenderung menunjukkan perilaku hate speech dengan tingkat intensitas 'kadang-kadang' di media sosial dengan jumlah subjek 123 orang (82,5\%). Selanjutnya, peneliti menentukan kategori hate speech berdasarkan usia subjek. 
Tabel 6. Kategori Hate Speech Berdasarkan Usia

\begin{tabular}{lccc}
\hline \multirow{2}{*}{ Usia } & \multicolumn{3}{c}{ Kategori } \\
\cline { 2 - 4 } $18-20$ & $7(9,0 \%)$ & Kadang & Sering \\
$21-23$ & $8(12,5 \%)$ & $68(87,2 \%)$ & $3(3,8 \%)$ \\
$24-25$ & $3(42,9 \%)$ & $51(79,7 \%)$ & $5(7,8 \%)$ \\
\hline
\end{tabular}

Berdasarkan hasil Tabel 6. diatas, antara subjek berjenis kelamin laki-laki maupun perempuan yang berusia antara 18-25 tahun, didapatkan hasil bahwa subjek yang menunjukkan intensitas perilaku hate speech 'jarang' berjumlah 18 orang (12,1\%), sementara hate speech dengan kategori 'kadang-kadang' ada sebanyak 123 orang (82,5\%) dengan kecenderungan paling banyak merupakan subjek yang berusia 18-23 tahun. Kemudian, hate speech dengan kategori 'sering' hanya sebanyak 8 orang $(5,4 \%)$.

Tabel 7. Kategori Harga Diri Berdasarkan Jenis Kelamin

\begin{tabular}{cccc}
\hline \multirow{2}{*}{ Harga Diri } & \multicolumn{3}{c}{ Jenis Kelamin } \\
\cline { 2 - 4 } & & L & P \\
\hline Sedang & $18(25,4 \%)$ & $53(74,6 \%)$ \\
Tinggi & $18(23,1 \%)$ & $60(76,9 \%)$ \\
\hline
\end{tabular}

Berdasarkan hasil Tabel 7. diatas, mendapatkan hasil bahwa subjek berjenis kelamin laki-laki menunjukkan tingkat harga diri sedang berjumlah 18 orang $(25,4 \%)$, sama halnya dengan tingkat harga diri yang tinggi, yakni 18 orang subjek $(23,1 \%)$. Sementara untuk subjek berjenis kelamin perempuan, ada sebanyak 53 orang $(74,6 \%)$ yang memiliki tingkat harga diri yang sedang sementara ada sebanyak 60 orang subjek $(76,9 \%)$ berjenis kelamin perempuan yang memiliki tingkat harga diri yang tinggi.

Tabel 8. Kategori Harga Diri Berdasarkan Usia

\begin{tabular}{lcc}
\hline \multirow{2}{*}{ Usia } & \multicolumn{2}{c}{ Kategori } \\
\cline { 2 - 3 } & \multicolumn{3}{c}{ Sedang } & Tinggi \\
\hline $18-20$ & $36(46,2 \%)$ & $42(53,8 \%)$ \\
$21-23$ & $32(50,0 \%)$ & $32(50,0 \%)$ \\
$24-25$ & $3(42,9 \%)$ & $4(57,1 \%)$ \\
\hline
\end{tabular}

Berdasarkan hasil dari Tabel 8. diatas, menunjukkan bahwa sebanyak 71 orang $(47,6 \%)$ subjek dengan rentang usia 18-23 tahun memiliki tingkat harga diri sedang dengan kecenderungan pada usia 18 tahun sebanyak 16 orang (10,7\%). Sementara itu, sebanyak 78 orang $(52,3 \%)$ subjek dengan rentang usia $18-23$ tahun memiliki tingkat harga diri yang tinggi dengan kecenderungan pada usia 19 tahun sebanyak 24 orang $(16,1 \%)$.

\section{DISKUSI}

Dari hasil analisis yang telah dilakukan, penelitian ini menunjukkan bahwa mayoritas subjek yang menunjukkan perilaku hate speech di media sosial cenderung 


\section{Cognicia}

http://ejournal.umm.ac.id/index.php/cognicia
ISSN 2658-8428

2020, VOL. 8, NO. 2, 296-311

memiliki tingkat harga diri yang tinggi. Hal ini dapat dilihat dari hasil penelitian yang telah dilakukan menunjukkan bahwa sebanyak 78 responden (52,3\%) dari total 149 responden berada dalam kategori harga diri tinggi, dengan rincian sebanyak 13 subjek $(16,7 \%)$ menunjukkan intensitas hate speech 'jarang', 29 subjek (37,2\%) menunjukkan intensitas hate speech 'kadang-kadang' dan 36 subjek (46,1\%) menunjukkan intensitas hate speech 'sering'. Penelitian ini sependapat dengan penelitian Ang dkk (2018) yang menyimpulkan bahwa perilaku intimidasi (psysical \& verbal bullying, relational bullying and gender-based bullying) akan menjadi lebih tinggi ketika harga diri individu tersebut lebih tinggi.

Berdasarkan hasil dari penelitian ini juga dapat diketahui bahwa subjek yang memiliki tingkat harga diri rendah adalah sebanyak $0(0 \%)$ subjek yang artinya subjek yang cenderung menunjukkan perilaku hate speech adalah subjek dengan tingkat harga diri sedang atau tinggi. Yang artinya, meskipun subjek mencapai aspek-aspek harga diri yang tinggi seperti mampu menerima diri, mampu mengontrol segala tindakannya, merasa mampu mencapai keinginan dan beradaptasi dengan baik, juga mampu menjalankan kewajibannya, subjek dengan tingkat harga diri yang sedang cenderung bisa menunjukkan perilaku hate speech di media sosial. Hal ini tidak sesuai dengan penelitian yang telah dilakukan oleh Butt dkk (2019) yang mendapatkan hasil bahwa harga diri memiliki korelasi negatif yang signifikan kejahatan cyber (hate speech termasuk di dalamnya) yang artinya penelitian tersebut menemukan bahwa individu yang terlibat dalam segala jenis kejahatan cyber memiliki tingkat harga diri yang rendah (low self-esteem).

Penelitian ini juga tidak sejalan dengan penelitian Morsunbul (2015) yang mendapatkan hasil bahwa ada hubungan negatif antara harga diri dan agresi yang artinya tingkat harga diri yang tinggi menurunkan tingkat agresi karena individu dengan harga diri rendah memiliki hubungan yang lemah dalam masyarakat dan dapat menimbulkan lebih banyak kenakalan dan agresi. Lalu pada penelitian ini juga tidak sesuai dengan hasil riset Olutunde (2017) yang juga mendapatkan hasil bahwa ada hubungan positif yang signifikan antara agresi dan harga diri yang artinya semakin rendah tingkat harga diri, maka semakin tinggi tingkat agresinya. Namun, penelitian ini cukup sejalan dengan penelitian yang dilakukan oleh Hayani \& Wulandari (2017) yang mendapatkan hasil bahwa tidak ada kecenderungan perilaku agresi ditinjau dari harga diri. Subjek dengan harga diri tinggi memiliki kecenderungan untuk melakukan tindakan agresi tersebut, begitu pula dengan subjek dengan harga diri yang rendah pun bisa memunculkan perilaku tersebut.

Penelitian ini melihat juga dari tiap aspek-aspek harga diri yang muncul pada pendukung pelaku hate speech seperti aspek " perasaan berharga", aspek "perasaan mampu" dan aspek "perasaan diterima" untuk menentukan aspek harga diri manakah yang paling tinggi pada subjek yang cenderung melakukan tindakan hate speech. Dari analisis yang telah dilakukan didapatkan hasil bahwa subjek yang menunjukkan perilaku hate speech cenderung melakukan aspek pertama yakni aspek "perasaan berharga". Hal tersebut dapat ditunjukkan dari skor mean yang didapat yaitu 1,69 yang lebih tinggi dari dua skor mean pada aspek 2 dan 3. Sehingga kemudian dapat 
disimpulkan bahwa subjek dengan perilaku hate speech kecederungan menunjukkan perilaku pada aspek 1 yaitu "perasaan berharga".

Hal ini sejalan dengan artikel penelitian yang telah dilakukan oleh Hayani dan Wulandari (2017) yang mendapatkan hasil bahwa tidak ada perbedaan signifikan pada perilaku agresi jika ditinjau dari karakteristik harga diri. Dimana harga diri rendah maupun tinggi sama-sama memiliki kecenderungan untuk melakukan tindakan agresi. Hal ini dikarenakan harga diri tinggi yang sering dikaitkan dengan adanya rasa bangga, egoisme, arogansi, kehormatan, narsisme, dan rasa superioritas. Hal ini juga dapat dijelaskan karena adanya threatened egotism yang menjelaskan bahwa agresi sering terjadi ketika seseorang merasa ada yang meremehkan atau menghina dirinya dan merusak citra dirinya. Individu dengan harga diri tinggi lebih rentan melakukan agresi ketika ia dihadapkan dengan sesuatu yang mengancam ego (Baumeister, Smart, \& Boden, 1996).

Penelitian ini juga melihat dari aspek-aspek perilaku hate speech seperti aspek "berdebat, menunjukkan ketidaksukaan atau ketidaksetujuan" dan aspek "bersikap sarkastis" untuk menentukan aspek manakah yang paling berpengaruh dalam membentuk perilaku hate speech tersebut. Hal tersebut dapat ditunjukkan dari skor mean yang didapatkan yaitu 2,6 yang lebih tinggi dari pada skor mean pada aspek pertama $(2,5)$. Sehingga kemudian dapat disimpulkan bahwa aspek "bersikap sarkastis" merupakan aspek yang paling banyak dilakukan oleh subjek.

Penelitian ini menggunakan subjek penelitian individu yang berusia 18-25 tahun, yang berdasarkan teori Hurlock (2012) merupakan masa dewasa awal dalam perkembangan. Hurlock mengemukakan bahwa dewasa awal merupakan suatu masa penyesuaian diri dengan cara hidup yang baru dan memanfaatkan kebebasan yang diperolehnya. Santrock (2013) juga mengatakan bahwa dewasa awal termasuk masa transisi, baik secara fisik maupun intelektual serta transisi peran sosial. Masa ini adalah masa beralihnya pandangan egosentris menjadi sikap empati. Arnett (2006) menjelaskan bahwa usia dewasa awal pada rentang waktu tersebut adalah ketika remaja menjadi lebih mandiri dan mengeksplorasi berbagai kemungkinan di dalam kehidupan. Arnett berpendapat bahwa pada periode perkembangan ini, bisa dipisahkan dari fase remaja dan dewasa muda. Masa dewasa muda adalah suatu demografis baru yang akan terus berubah dan pada usia 20 tahunan akan selalu bergulat dengan eksplorasi identitas, ketidakstabilan, fokus pada diri sendiri dan perasaan diantaranya. Arnett menyebut periode ini sebagai peraturan tanpa peraturan karena dewasa muda melakukan berbagai aktivitas tetapi tidak dibatasi dengan peraturan apapun.

Teori ini sesuai dengan hasil penelitian yang telah dilakukan bahwa subjek yang menunjukkan perilaku hate speech adalah subjek yang dimana perilakunya didasari oleh kebencian (hate). Subjek cenderung menunjukkan sikap-sikap kebencian seperti menjauhkan diri, menolak untuk dekat atau menyangkal keintiman dengan orang lain, perasaan ini muncul ketika individu tersebut merasa adanya perbedaan karakteristik tertentu dari target hate speech entah dari ras/agama yang berbeda atau karena suatu tindakan yang artinya subjek bergulat dengan identitas dirinya sendiri. Subjek yang melakukan hate speech juga cenderung melakukan tindakan seperti mengurangi/mengubah karakteristik targetnya sebagai salah satu caranya untuk 


\section{Cognicia}

membangkitkan dan menyebarkan kebencian dalam kelompok pada target tersebut tanpa menyadari batasan atau pun peraturan misalnya dengan menyebarkan rumor dan gosip yang belum tentu kebenarannya. Oleh karena didasari rasa kebencian (hate) tersebut, subjek bisa memunculkan tindakan-tindakan hate speech seperti menghina, mencemarkan nama baik, penistaan, perbuatan tidak menyenangkan, memprovokasi, menghasut dan menyebarkan berita bohong (SE Kapolri, 2015).

Harga diri dipandang sebagai "evaluasi umum terhadap diri sendiri". Namun penilaian seperti itu bisa menjadi positif mau pun negatif tergantung penilaian masingmasing. Penilaian yang positif atau negatif yang dibuat akan sangat mempengaruhi fungsi kehidupan sehari-hari. Harga diri yang positif berfungsi sebagai pencegah hal yang dapat menimbulkan pengaruh negatif dalam meningkatkan kesehatan, produktivitas, kepuasan dan interaksi sosial. Namun, penilaian yang negatif terhadap harga diri dapat menjadi faktor pencetus masalah sosial secara simultan atau bersamaan yang nantinya berkontribusi pada berbagai masalah mental seperti kekerasan, agresi, dan perilaku yang beresiko tinggi. Leary dkk (1995) mengemukakan bahwa salah satu kontributor utama dalam perilaku dan masalah emosional adalah harga diri yang rendah. Namun beberapa peneliti juga mengklaim jika ada hubungan antara agresi dan harga diri yang tinggi (Butt dkk, 2019). Beberapa pendapat diatas sesuai dengan penelitian ini yang mana tidak keseluruhan subjek menunjukkan perilaku hate speech.

Ada sebanyak 8 orang (11,3\%) yang dikategorikan sebagai subjek dengan intensitas perilaku hate speech 'jarang' yang memiliki tingkat harga diri sedang, yang artinya ketika berbeda subjek yang digunakan, ada kemungkinan hasil akan menjadi berbeda. Sehingga dapat disimpulkan bahwa tingkat harga diri yang rendah mau pun tinggi masih berkemungkinan untuk melakukan tindakan hate speech. Kemudian, penelitian lain seperti yang dilakukan Irlandia (Butt dkk, 2019), mengklaim bahwa agresi seperti cyberbullying memiliki hubungan dengan harga diri yang tinggi. Hal itu sejalan dengan penelitian ini dimana subjek yang menunjukkan perilaku hate speech ratarata memiliki tingkat harga diri yang tinggi.

Penelitian ini pun sesuai dengan penjelasan Baron dkk (Sarwono, 2018) bahwa ketika individu termotivasi untuk memperoleh atau melihat diri yang positif, individu tersebut dapat mengalami bias dalam menilai hasil yang diperoleh. Ketika hasil yang diperoleh positif, maka individu tersebut merasa bahwa dirinyalah yang bertanggung jawab atas hasil tersebut, sementara ketika hasil yang didapat negatif, maka individu tersebut akan mengalihkan hal tersebut pada orang lain, seperti yang ditunjukkan aspek hate speech pada penelitian ini yaitu aspek "bersikap sarkastis" yang merupakan aspek tertinggi yang muncul dalam perilaku hate speech. Kemudian Sarwono (2018) juga menjelaskan bahwa harga diri tinggi tidak selalu berpengaruh positif terhadap tingkah laku. Bullying, narsisme, dan eksibisionisme adalah contoh tingkah laku negatif yang dilakukan oleh individu dengan harga diri tinggi. Pendukung pelaku hate speech yang memiliki harga diri tinggi dalam penelitian ini sesuai dengan penjelasan Sarwono (2018) dimana harga diri yang tinggi mencerminkan superioritas terhadap orang lain dan individu akan termotivasi untuk terus mempertahankannya. Ketika ada situasi yang dipersepsikan individu tersebut akan mengancam superioritasnya, maka muncul perilaku hate speech yang bertujuan untuk mempertahankannya. 


\section{HATE SPEECH, SELF ESTEEM, SOCIAL MEDIA}

Penelitian dengan mengusung tentang perilaku hate speech dalam penelitian ini masih jarang diteliti di Indonesia terutama dalam dunia psikologi sehingga menjadi salah satu keunikan dalam penelitian ini. Subjek yang dipilih dalam penelitian pun merupakan subjek yang pernah menunjukkan perilaku hate speech dan masih jarang ditemui meskipun media sosial kerap kali menjadi bahan penelitian. Hasil dari penelitian ini sudah cukup jelas dan diharapkan dapat memberikan manfaat bagi bidang ilmu psikologi serta pembaca. Namun, penelitian ini pun tak lepas dari kekurangan, dikarenakan peneliti hanya berfokus pada salah satu faktor penyebab agresi verbal atau penyebab munculnya perilaku hate speech tersebut di media sosial. Kelemahan lain dalam penelitian ini adalah skala hate speech yang telah digunakan oleh peneliti masih kurang merujuk ke dalam pengertian dan konsep hate speech itu sendiri sehingga hanya ada 4 nomor (nomor 9-12) yang bisa digunakan untuk menganalisis perilaku hate speech di media sosial.

\section{SIMPULAN DAN IMPLIKASI}

Berdasarkan dari hasil penelitian yang dilakukan, dapat disimpulkan bahwa individu yang menunjukkan perilaku hate speech cenderung memiliki tingkat harga diri yang tinggi, yang artinya meskipun subjek mencapai aspek-aspek harga diri yang tinggi, cenderung bisa memunculkan perilaku hate speech di media sosial.

Implikasi dari penelitian ini yaitu bagi individu yang pernah atau tanpa sengaja melakukan tindakan hate speech atau bahkan pada individu yang aktif menggunakan media sosial mampu membatasi perilakunya dalam bersosialisasi secara online. Individu tersebut mampu mengarahkan perilaku-perilaku yang menunjukkan perasaan superioritasnya yang disebabkan oleh harga diri yang tinggi tersebut untuk mengaplikasikannya ke dalam hal-hal yang lebih positif. Bagi peneliti selanjutnya, disarankan untuk menggunakan atau membuat item pada skala hate speech berdasarkan aspek serta indikator perilaku agresi yang disesuaikan dengan konsep hate sehingga item akan lebih sesuai dengan konteks perilaku hate speech dan disarankan pula menggunakan kalimat yang lebih mengungkap atau menggambarkan perilakunya serta menyertakan objek yang menjadi target hate speech untuk memperjelas pernyataan tersebut.

\section{REFERENSI}

Abrams, A. (2017). The psychology of hate. Retrieved from https://www.psychologytoday .com/us/blog/nurturing-selfcompassion/201703/the-psychology-hate.

Agung, I.M., Harmaini, \& Makbul, C. (2016). Self esteem, siri', dan perilaku agresif pada suku bugis: sisi gelap self esteem tinggi. Jurnal Psikologi, 12(1).

Ang, C.S., Chong, C.P., Cheong, S.W., Lee, C.Y., Tang, Z.H., \& Liew C.Y. (2018). Selfesteem and tendency of bullying among primary school children. Jurnal Romanian of Psychology, 20(1), 11-17.

Anugrahadi, A. (2018). Penyerahan tersangka Ahmad Dhani dari polisi ke kejaksaan tunggu waktu. Retrieved from https://www.liputan6.com/news/read/3292300/ 
penyerahan-tersangka-ahmad-dhani-dari-polisi-ke-kejaksaan-tunggu-waktu. Diakses pada 16 Februari 2018, pukul 12:03 WIB.

Anwar, F. (2015). Fenomena penyebar hate speech dilihat dari kacamata psikologi. https://health.detik.com/berita-detikhealth/d-3060430/fenomena-penyebarhate-speech-dilihat-dari-kacamata-psikologi. Diakses pada 03 November 2015, pukul 09:03 WIB.

Anwarsyah, F. \& Gazi. (2017). Pengaruh loneliness, self control, dan self esteem terhadap perilaku cyberbullying pada mahasiswa. Jurnal Tazkiya of Psychology, 5(2).

APJII (Asosiasi Penyelenggara Jasa Internet Indonesia). (2017). Penetrasi dan Perilaku Pengguna Internet di Indonesia. Retrieved from https://apjii.or.id/content/read/ 39/342/Hasil-Survei-Penetrasi-dan-Perilaku-Pengguna-Internet-Indonesia2017.

Auwal, A.M. (2018). Social media and hate speech: analysis of comments on biafra agitations, arewa youth's ultimatum and their implications on peaceful coexistence in nigeria. Journal MCC, 2(1).

Bashori, K. \& Hidayat, K. (2016). Psikologi sosial, aku kami, dan kita. Jakarta: Penerbit Erlangga.

Butt, S.S., Jamil, F. \& Khalid, R. (2019). Cyberbullying, self esteem and interpersonal trust in young adults. Journal of Social and Clinical Psychology, 17(1), 38-46.

Cahyono, A.S. (2016). Pengaruh media sosial terhadap perubahan sosial masyarakat di Indonesia. Jurnal Ilmu Sosial dan Ilmu Politik, 9(1), 140-157.

Chaq, M.C., Suharnan, \& Rini, A.P. (2018). Religiusitas, kontrol diri, dan agresivitas verbal remaja. Jurnal Psikologi, 27(2), 20-30.

Dayakisni, T. \& Hudaniah. (2012). Psikologi sosial (5th ed). Malang: UMM Press.

Eliani, J., Masturah, A.N., \& Yuniardi, M.S. Fanatisme dan perilaku agresi verbal di media sosial pada penggemar idola K-Pop. Jurnal Psikohumaniora, 3(1), 59-72.

Good Therapy. (2019). Hatred. Retrieved from https://www.goodtherapy.org/blog Lpsychpedia/hatred

Harefa, N.R. (2017). Implikasi perubahan undang-undang informasi dan transaksi elektronik terhadap tindak pidana ujaran kebencian (hate speech) (skripsi tidak terpublikasi). Universitas Sumatera Utara, Sumatera Utara.

Harlock, E.B. (2012). Psikologi Perkembangan, Suatu Pendekatan Sepanjang Rentang Kehidupan. Jakarta: Erlangga.

Hastuti, L.W. (2018). Kontrol diri dan agresi: tinjauan meta-analisis. Jurnal Buletin Psikologi, 26(1), 42-53.

Hassan, A., Singh, B., \& Wani, M.A. (2017). Agression and self esteem among teenagers. Jurnal Intelektual dan Perkembangan Disabilitas, 3(2).

Hayani, I.M.N \& Wulandari, P.Y. (2017). Perbedaan kecenderungan perilaku agresi ditinjau dari harga diri pada mahasiswa. Jurnal Psikologi Pendidikan dan Perkembangan, 6, 32-42.

Heller, B. \& Magid, L. (2019). The Parent's and Educator's Guide to Combating Hate Speech. Retrieved from https://www.connectsafely.org/hatespeech.

Hootsuite. (2017). Indonesia Digital 2019: Media Sosial. Retrieved from https://websindo.com/indonesia-digital-2019-media-sosial. 


\section{HATE SPEECH, SELF ESTEEM, SOCIAL MEDIA}

Husaini, U. \& Purnomo, S.A. (2008). Metodologi Penelitian Sosial. Jakarta: PT. Bumi Aksara

Kumala, I.D., \& Sentana, M.A. (2017). Agresivitas dan kontrol diri pada remaja di Banda Aceh. Jurnal Sains Psikologi, 6(2), 51-55.

Mangantibe, V. (2016). Ujaran Kebencian dalam surat edaran KAPOLRI nomor : SE/6/X/2015 tentang penanganan ucapan kebencian (hate speech). Jurnal Lex Crimen, 5(1).

Mardiyati, I. (2017). Fenomena hate speech di sosial media dalam perspektif psikologi islam. Jurnal Pemikiran Pendidikan Islam, 11(1), 31-38.

Mulawarman \& Nurfitri, A.D. (2017). Perilaku pengguna media sosial beserta implikasinya ditinjau dari perspektif psikologi sosial terapan. Jurnal Buletin Psikologi, 25(1), 36-44.

Mursunbul, U. (2015). The effect of identity development, self-esteem, low self-control and gender on aggression in adolescence and emerging adulthood. Jurnal Penelitian Pendidikan, 61, 99-116.

Myanmar, P. (2015). Hate speech: a study of print, movies, songs and social media in Myanmar. Artikel ilmiah.

Nuryanti. (2020). Pendukung Anies Baswedan dilaporkan makar setelah dianggap bawa spanduk ujaran kebencian pada Jokowi. Retrieved from https://www.tribunnews.com/nasional/2020/01/19/pendukung-anies-baswe dan-dilaporkan-makar-setelah-dianggap-bawa-spanduk-ujaran-kebencianpada-jokowi Diakses pada Minggu, 19 Januari 2020, pukul 05:36 WIB.

Olutunde, Olatunji S. (2017). Influence of perceived stress, anxiety, and self esteem on aggressive behavior among teenagers. Jurnal IJISET, 4(6).

Papalia, D. E., Old, S. W., Feldman, \& R. D. (2008). Human Development (terjemahan A. K. Anwar). Jakarta: Prenada Media Group.

Rohman, F. (2016). Analisis meningkatnya kejahatan cyberbullying dan hate speech menggunakan berbagai media sosial dan metode pencegahannya. Jurnal Sniptek.

Santrock, J.W. (2013). Life-Span Development, Edisi 13. Jakarta: Erlangga.

Saputra, A. (2018). Terbukti fitnah Jokowi, Arseto tetap dihukum 2 tahun penjara. https://news.detik.com/berita/d-4291031/terbukti-fitnah-jokowi-arseto-tetapdihukum-2-tahun-penjara. Diakses pada Rabu, 7 November 2018, pukul 11:43 WIB.

Sarwono, S.W. (2018). Psikologi Sosial, Edisi 2. Jakarta: Salemba Humanika.

Sugiyono. (2010). Metode Penelitian Kuantitatif Kualitatif dan RED. Bandung: Alfabeta. Sugiyono. (2011). Metode Penelitian Kuantitatif, Kualitatif dan RED. Bandung: Alfabeta. Widiyanto \& Ibnu. (2008). Pointers: Metodologi Penelitian. Semarang: CV Dikalia. 